\title{
Petrographic and Geochemical Data for Cenozoic Volcanic Rocks of the Bodie Hills, California and Nevada
}

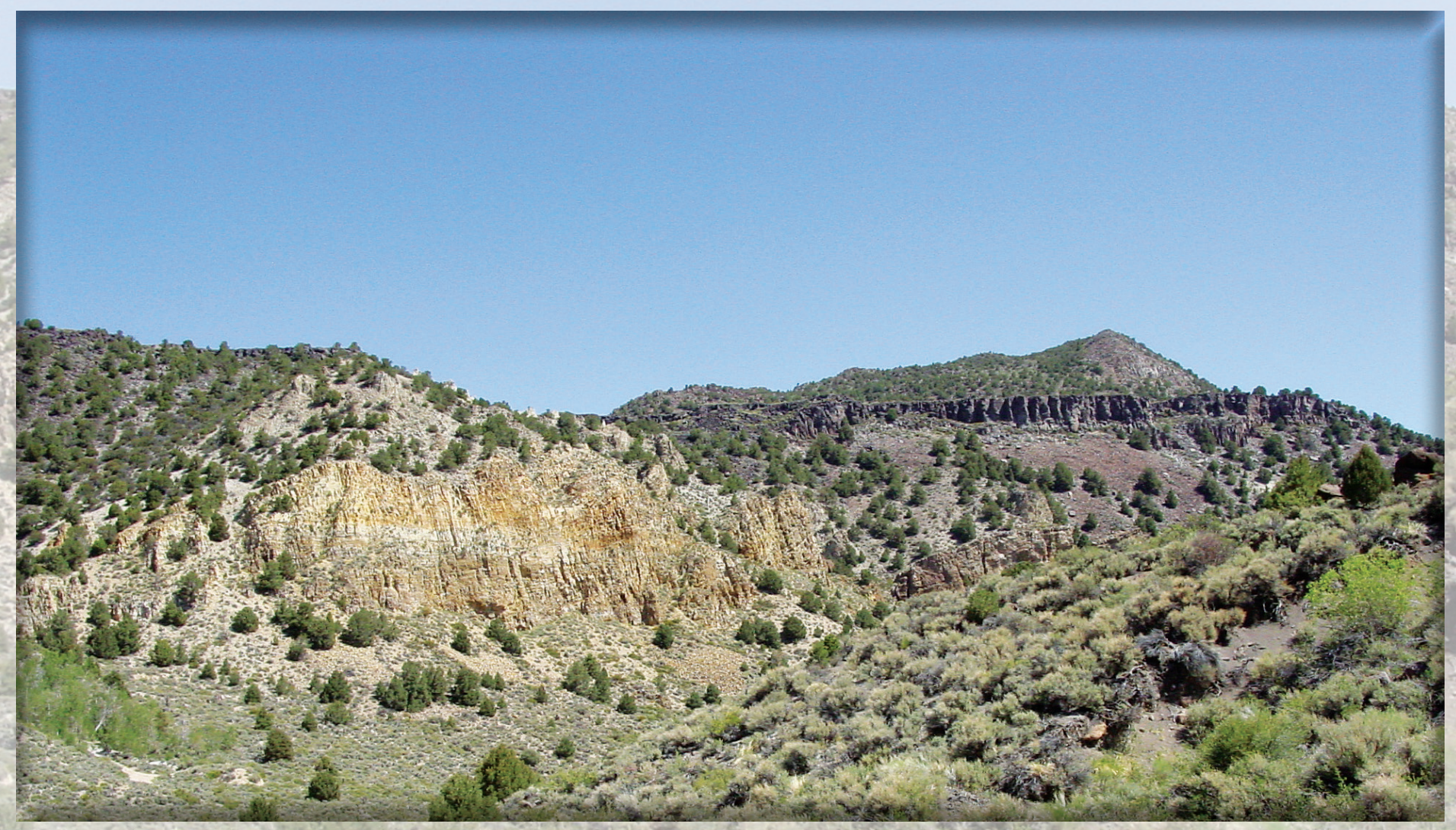

Data Series 764

Version 1.1, August 2016

U.S. Department of the Interior

U.S. Geological Survey 
Cover: In Bodie Creek, columnar-jointed rhyolite of Bodie Creek (yellowish-tan outcrops on the left side of the photo as well as the darker peak on the skyline) are unconformably overlain by thin, trachyandesite of Beauty Peak lava flows that cap slopes in the middle distance. The rhyolite of Bodie Creek is part of the Miocene Bodie Hills volcanic field, whereas the trachyandesite of Beauty Peak is part of the Pliocene-Pleistocene Aurora volcanic field. 


\section{Petrographic and Geochemical Data for Cenozoic Volcanic Rocks of the Bodie Hills, California and Nevada}

By Edward A. du Bray, David A. John, Stephen E. Box, Peter G. Vikre,

Robert J. Fleck, and Brian L. Cousens

Data Series 764

Version 1.1, August 2016

U.S. Department of the Interior

U.S. Geological Survey 


\title{
U.S. Department of the Interior SALLY JEWELL, Secretary
}

\section{U.S. Geological Survey Suzette M. Kimball, Director}

\author{
U.S. Geological Survey, Reston, Virginia \\ First release: 2013 \\ Revised: August 2016 (ver 1.1)
}

For more information on the USGS — the Federal source for science about the Earth, its natural and living resources, natural hazards, and the environment-visit http://www.usgs.gov or call 1-888-ASK-USGS.

For an overview of USGS information products, including maps, imagery, and publications, visit http://store.usgs.gov/.

Any use of trade, firm, or product names is for descriptive purposes only and does not imply endorsement by the U.S. Government.

Although this information product, for the most part, is in the public domain, it also may contain copyrighted materials as noted in the text. Permission to reproduce copyrighted items must be secured from the copyright owner.

Suggested citation:

du Bray, E.A., John, D.A., Box, S.E., Vikre, P.G., Fleck, R.J., and Cousens, B.L., 2016, Petrographic and geochemical data for Cenozoic volcanic rocks of the Bodie Hills, California and Nevada (ver. 1.1, August 2016): U.S. Geological Survey Data Series 764, 10 p., http://dx.doi.org/10.3133/ds764.

ISSN 2327-638X (online) 


\section{Contents}

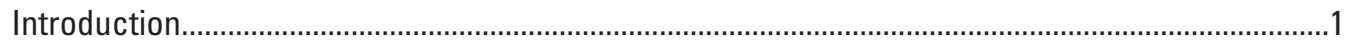

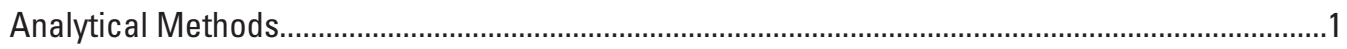

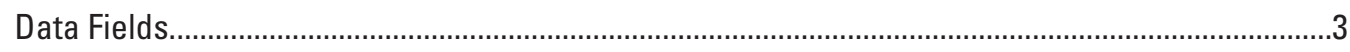

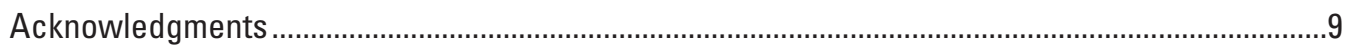

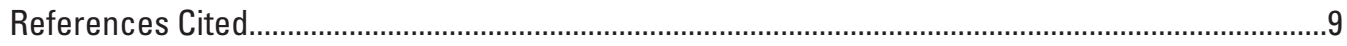

Appendix 1. Status and Treatment of Samples ............................................................................... link

Appendix 2. Petrographic Data for Rock Samples ......................................................................... link

Appendix 3. Geochemical Data for Rock Samples....................................................................... link

\section{Figure}

1. Index map showing location of the Bodie Hills volcanic field, California and Nevada ....2

\section{Tables}

1. Definition and characterization of data fields included in appendix 1 (status and treatment of samples) ........................................................................................................

2. Definition and characterization of data fields included in appendix 2 (petrographic

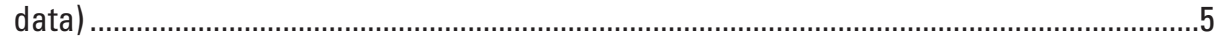

3. Definition and characterization of data fields included in appendix 3 (geochemical

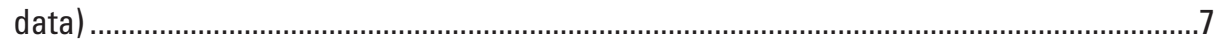





\title{
Petrographic and Geochemical Data for Cenozoic Volcanic Rocks of the Bodie Hills, California and Nevada
}

\author{
By Edward A. du Bray, David A. John, Stephen E. Box, Peter G. Vikre, Robert J. Fleck, and Brian L. Cousens
}

\section{Introduction}

The purpose of this report is to present available petrographic and geochemical data for unmineralized rock samples, principally volcanic rocks, of the Tertiary Bodie Hills volcanic field and to make those data available to ongoing petrogenetic investigations of these rocks. Most of the data presented here were derived from samples collected between 2000-2013, but some of the geochemical data, compiled from a variety of sources, pertain to samples collected during prior investigations; all samples collected during investigations prior to 2000 are identified by "OTH" in the "Collector" data field (appendix 1). When more than one sample was collected at a sample site, a single representative sample from the site was selected, and only petrographic and geochemical information pertinent to that sample are included in the data compilations that accompany this report.

The middle to late Miocene Bodie Hills volcanic field (BHVF) is a large $\left(>700 \mathrm{~km}^{2}\right)$, long-lived $(\approx 9$ million years [m.y.]), but episodic, eruptive center (John and others, 2012) in the southern segment of the ancestral Cascades arc north of Mono Lake, California (fig. 1). The field is near the west side of the Walker Lane and the northwest end of the Mina deflection where structures related to these tectonic features might have localized BHVF magmatism. The BHVF includes at least 32 volcanic rock units. The field includes four trachyandesite stratovolcanoes that were emplaced along its margins and numerous silicic trachyandesite to rhyolite flow dome complexes that were generally localized more centrally. Volcanism in the BHVF was discontinuous through time, with two peak periods of eruptive activity, including an early period between $\approx 15.0$ to $12.6 \mathrm{Mega}$-annum $(\mathrm{Ma})$ that formed large stratovolcanoes and a later period between $\approx 9.9$ to 8.0 Ma dominated by emplacement of large silicic trachyandesitedacite lava domes. A final period of small-volume silicic dome emplacement occurred at about $6 \mathrm{Ma}$.

Compositions of Bodie Hills volcanic rocks vary from $\approx 50$ to 78 weight percent $\mathrm{SiO}_{2}$, although rocks with $<55$ weight percent $\mathrm{SiO}_{2}$ are rare. Rock compositions form a high-potassium $(\mathrm{K})$ calc-alkaline series with pronounced negative titanium-phosphorus-niobium-tantalum anomalies and high barium/niobium, barium/tantalum, and lanthanum/ niobium typical of subduction-related continental margin arcs
(Gill, 1981). Most BHVF rocks are porphyritic, commonly containing 15-35 volume percent phenocrysts of plagioclase, pyroxene, and hornblende \pm biotite. Although the oldest eruptive centers have the most mafic compositions, erupted rock compositions oscillated between mafic and intermediate to felsic compositions through time. Following a 2 m.y. hiatus in volcanism, post subduction rocks of the $\approx 3.9$ - to 0.1-Ma, bimodal, high-K Aurora volcanic field were erupted onto the BHVF. Formation of the Bodie Hills volcanic field spanned the transition between subduction of the Farallon plate beneath the west coast of North America and the establishment of a transform plate margin at about $10 \mathrm{Ma}$. However, significant volcanism in the Bodie Hills persisted to $8 \mathrm{Ma}$ without apparent changes in rock composition or style of eruption.

Numerous hydrothermal systems were operative in the Bodie Hills during the Miocene. Structurally focused hydrothermal systems formed large epithermal gold-silver vein deposits in the Bodie and Aurora mining districts. Economically important hydrothermal systems in the Bodie Hills are temporally related to intermediate- to siliciccomposition dome complexes (John and others, 2012).

\section{Analytical Methods}

Standard petrographic microscope techniques were employed to identify phenocryst minerals and estimate their relative abundances in 706 samples of volcanic rocks from the Bodie Hills (appendix 2; see Data Fields, below). Phenocryst size and crystallinity, rock textures, groundmass characteristics, and accessory mineral assemblages were also tabulated for each sample. Characteristics of the Mesozoic basement rocks, including granitoids of the Sierra Nevada batholith and their metamorphic host rocks, were also established by reconnaissance petrographic study of 31 samples. Relative mineral abundances in 20 Mesozoic granitoid rock samples were further refined using a binocular microscope to count at least 1,000 points on slabs stained using the method of Laniz and others (1964). Additional petrographic characteristics for 21 samples of the Aurora volcanic field were compiled from the literature (Lange and Carmichael, 1996). 


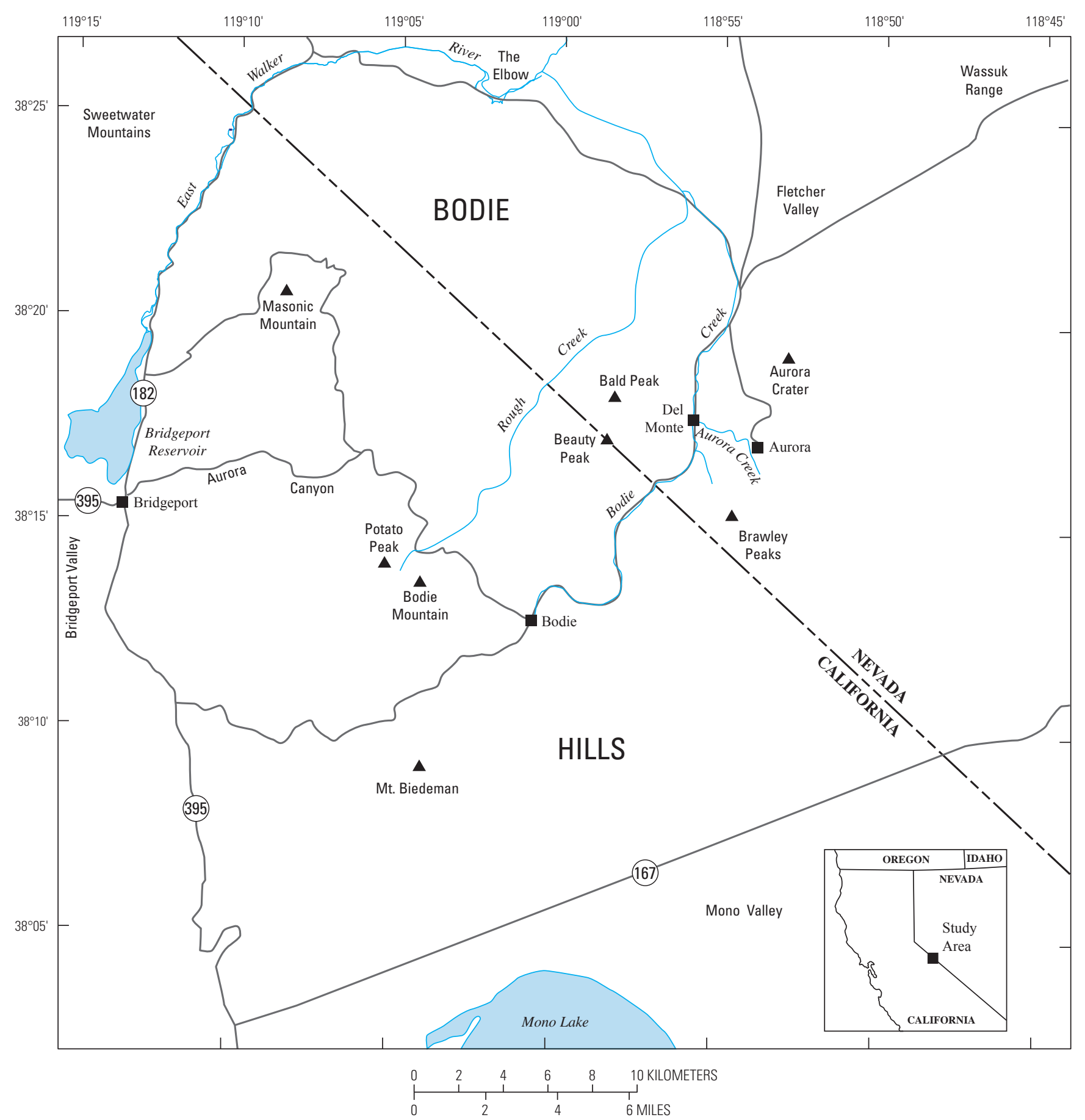

Figure 1. Index map showing location of the Bodie Hills volcanic field, California and Nevada 
Whole-rock chemical analyses (556 samples) for samples collected between 2000 and 2013 were performed in analytical laboratories of SGS Minerals, Toronto, Canada (appendix 3; see Data Fields, below). Major oxide abundances (recalculated to 100 percent, volatile-free) were determined by wavelength dispersive X-ray fluorescence spectrometry. A 55-element method that uses a combination of inductively coupled plasma-atomic emission spectrometry and inductively coupled plasma-mass spectrometry was used to determine trace element abundances. These chemical data are also archived in the National Geochemical Database (U.S. Geological Survey, 2008). Pertinent analytical methods are described by Taggart (2002). Compositions of an additional 109 samples of Bodie Hills rocks from published sources are included in this data compilation. These samples were analyzed by different laboratories employing diverse analytical techniques, which resulted in data of variable quality for a highly variable set of constituents. Laboratories, techniques, and the analyzed constituents are documented in the sources (identified in appendix 1; see Data Fields, below) from which these data were compiled.

Although every effort was made to collect only unaltered samples, a review of the geochemical data indicates that a small subset of the analyzed samples were affected by post-magmatic hydrothermal alteration. Samples with any of the following characteristics are considered to be altered: $\mathrm{SiO}_{2}$ abundances greater than 78 percent, volatile (loss on ignition) content greater than 4 percent (excluding hydrated vitrophyres), $\mathrm{Na}_{2} \mathrm{O}$ abundances less than 1 percent, $\mathrm{K}_{2} \mathrm{O}$ abundances greater than 7.5 percent, or $\mathrm{Na}_{2} \mathrm{O} / \mathrm{K}_{2} \mathrm{O}$ less than 0.5 . Primary igneous rock compositions of samples with any of these characteristics probably have not been preserved; these samples and the type of alteration they experienced are identified by entries in the Alt_Desc column in appendix 1. In addition, samples with initial analytic totals less than 98 percent probably indicate inaccurate analyses (see entries in the total_I_pct column of appendix 3).

\section{Data Fields}

Sample characterization, petrographic, and geochemical data are presented in columns or sets of related columns (appendixes 1, 2, and 3) in three Microsoft Excel 2003 workbooks (.xls format). The contents of appendix 1 (data fields defined in table 1) constitute basic characterization including sample location, sample treatment, lithologic characterization for each sample, and age of the unit represented by each sample. Appendix 2 contains petrographic observations for each sample (data fields defined in table 2). Appendix 3 contains geochemical data for analyzed samples (data fields defined in table 3). Geochemical data in some worksheet cells may appear to be more precise than displayed values, but the implied precision is a misleading artifact of computational processes (for instance, recalculation to 100-percent volatile free) used to create data-cell contents. Blank cells in the worksheet appendixes indicate null values or that no data are available. In appendix 3 (geochemistry data), some blank cells reflect abundances that were reported as "less than the detection limit"; these values were replaced by blank cells to enable statistical analysis of the uncensored data.

Table 1. Definition and characterization of data fields included in appendix 1 (status and treatment of samples).

\begin{tabular}{|c|c|}
\hline FIELD_NAME & FIELD_DESCRIPTION \\
\hline Field_ID & $\begin{array}{l}\text { Field-assigned sample identifier; Field_ID entries link data for individual rows to the contents of particular rows in the } \\
\text { other appendixes and, for USGS samples, to the National Geochemical Database. }\end{array}$ \\
\hline EquivSpl & Co-located sample(s) \\
\hline Latitude & $\begin{array}{l}\text { In decimal degrees, relative to the North American Datum of 1927; locations (with four or five significant figures) of } \\
\text { samples collected between } 2000 \text { and } 2012 \text { were determined using global positioning system technology and are accurate } \\
\text { within several to tens of meters, whereas locations (with two or three significant figures) of some previously collected } \\
\text { samples are accurate within hundreds of meters. Latitude as a positive value (northern hemisphere). }\end{array}$ \\
\hline TS & $\mathrm{X}$, thin section of sample prepared and examined using a petrographic microscope (see appendix 2) \\
\hline PTS & $\mathrm{X}$, polished thin section of sample prepared and examined using a petrographic microscope (see appendix 2) \\
\hline
\end{tabular}


Table 1. Definition and characterization of data fields included in appendix 1 (status and treatment of samples).-Continued

\begin{tabular}{|c|c|}
\hline FIELD_NAME & FIELD_DESCRIPTION \\
\hline REF & X, reference sample collected; SS, stained slab of Mesozoic granitoid samples prepared for modal analysis (see appendix 2) \\
\hline Ar_Ar & $\mathrm{X}$, sample age determined by ${ }^{40} \mathrm{Ar} /{ }^{39} \mathrm{Ar}$ geochronology (John and others, 2012) \\
\hline Fe_TiOx & $\mathrm{X}, \mathrm{Fe}-\mathrm{Ti}$ oxide mineral compositions (not included in database) determined via microprobe analysis (unpublished data) \\
\hline Strat_Name & Stratigraphic unit name (John and others, 2012) \\
\hline Ign_Form & Form (lava, ash-flow tuff, plug, stock, and so forth) of the igneous rock represented by each sample \\
\hline Alt_Desc & $\begin{array}{l}\text { Terms used to characterize altered samples are secondary silica, hydrated glass (where hydration is extensive), loss on } \\
\text { ignition greater than 4, potassic, propylitic, silicified, total less than 98, argillic, and alkali metasomatism; terms are } \\
\text { applied in accordance with their standard usage, defined for instance by Guilbert and Park (1986). }\end{array}$ \\
\hline Rad_Age & $\begin{array}{l}\text { Radiometric age, in million years; in some instances, multiple geochronologic age determinations have been obtained for a } \\
\text { single sample; all multiple ages are separated by semi-colons. }\end{array}$ \\
\hline Uncert & Age analytical uncertainty, in million years, associated with age determinations reported in "Rad_Age" \\
\hline Age_Src & $\begin{array}{l}\text { Source of age data: A, Silberman and Chesterman (1972); B, Silberman and McKee (1972); C, Fleck and others (2015); D, } \\
\text { Gilbert and others (1968); E, Lange and others (1993) }\end{array}$ \\
\hline
\end{tabular}


Table 2. Definition and characterization of data fields included in appendix 2 (petrographic data):

\begin{tabular}{|c|c|}
\hline FIELD_NAME & FIELD_DESCRIPTION \\
\hline Field_ID & $\begin{array}{l}\text { Field-assigned sample identifier; Field_ID entries link data for individual rows to the contents of particular rows in the } \\
\text { other appendices and, for USGS samples, to the National Geochemical Database }\end{array}$ \\
\hline AbdQtz & $\begin{array}{l}\text { Microscope-based estimate of abundance of quartz relative to the whole rock, in volume percent. TR, trace }(<0.5 \text { volume } \\
\text { percent) amounts; abd, abundant ( } \geq 20 \text { volume percent); X, present; ?, presence uncertain }\end{array}$ \\
\hline AbdP1 & $\begin{array}{l}\text { Microscope-based estimate of abundance of plagioclase relative to the whole rock, in volume percent } T R \text {, trace }(<0.5 \\
\text { volume percent) amounts; abd, abundant ( } \geq 20 \text { volume percent }) ; X \text {, present }\end{array}$ \\
\hline AbdHbl & $\begin{array}{l}\text { Microscope-based estimate of abundance of hornblende relative to the whole rock, in volume percent. TR, trace }(<0.5 \\
\text { volume percent) amounts; ??, presence uncertain }\end{array}$ \\
\hline $\mathrm{AbdBt}$ & $\begin{array}{l}\text { Microscope-based estimate of abundance of biotite relative to the whole rock, in volume percent; TR, trace }(<0.5 \text { volume } \\
\text { percent) amounts }\end{array}$ \\
\hline Cpx_Opx & $\begin{array}{l}\text { Presence of clinopyroxene }(\mathrm{C}) \text { and orthopyroxene }(\mathrm{O}) \text {; if both are present, then letter designation for dominant pyroxene is } \\
\text { uppercase, and letter designation for subordinate pyroxene follows in lower case; if both are capitalized the two pyrox- } \\
\text { enes are approximately equally abundant }\end{array}$ \\
\hline AbdOl & $\begin{array}{l}\text { Microscope-based estimate of abundance of olivine relative to the whole rock, in volume percent. TR, trace }(<0.5 \text { volume } \\
\text { percent) amounts; ??, presence uncertain }\end{array}$ \\
\hline AbdOpq & $\begin{array}{l}\text { Microscope-based estimate of abundance of opaque iron-titanium oxide minerals relative to the whole rock, in volume } \\
\text { percent. TR, trace ( }<0.5 \text { volume percent) amounts; X, present; ?, presence uncertain }\end{array}$ \\
\hline TotXls & $\begin{array}{l}\text { Microscope-based estimate of total phenocryst content relative to the whole rock, in volume percent; TR, trace }(<0.5 \\
\text { volume percent) amounts }\end{array}$ \\
\hline ClrIndx & $\begin{array}{l}\text { Microscope-based estimate of color index (sum of the abundances of hornblende, biotite, pyroxene, olivine, and opaque } \\
\text { iron-titanium oxide minerals) in volume percent; TR, trace ( }<0.5 \text { volume percent) amounts }\end{array}$ \\
\hline $\mathrm{AgsBt}$ & Microscope-based estimate of average grain size of biotite phenocrysts, in millimeters \\
\hline AgsPx & Microscope-based estimate of average grain size of pyroxene phenocrysts, in millimeters \\
\hline $\mathrm{AgsOl}$ & Microscope-based estimate of average grain size of olivine phenocrysts, in millimeters \\
\hline AgsOpq & Microscope-based estimate of average grain size of opaque iron-titanium oxide phenocrysts, in millimeters \\
\hline MgsQtz & Microscope-based estimate of maximum grain size (length) of largest quartz phenocryst, in millimeters \\
\hline MgsAlkFld & Microscope-based estimate of maximum grain size (length) of largest alkali feldspar phenocryst, in millimeters \\
\hline MgsPl & Microscope-based estimate of maximum grain size (length) of largest plagioclase phenocryst, in millimeters \\
\hline $\mathrm{MgsHbl}$ & Microscope-based estimate of maximum grain size (length) of largest hornblende phenocryst, in millimeters \\
\hline MgsBt & Microscope-based estimate of maximum grain size (length) of largest biotite phenocryst, in millimeters \\
\hline MgsPx & Microscope-based estimate of maximum grain size (length) of largest pyroxene phenocryst, in millimeters \\
\hline $\mathrm{MgsOl}$ & Microscope-based estimate of maximum grain size (length) of largest olivine phenocryst, in millimeters \\
\hline MgsOpq & Microscope-based estimate of maximum grain size (length) of largest opaque iron-titanium oxide phenocryst, in millimeters \\
\hline Texture & $\begin{array}{l}\text { Characteristic petrographic textures as determined by microscopic observation-abbreviations: A, aphyric; APH, aphanitic; } \\
\text { F, fragmental; fine grnd, fine grained; FL, flow laminated; H, hyalophitic; HC, holocrystalline; HG, hypidiomorphic } \\
\text { granular; I, intersertal; IG, intergranular; IN, inequigranular; med grnd, medium-grained; P, porphyritic; PT, pilotaxitic; } \\
\text { S, seriate; SPH, spherulitic; T, trachytic; V, vesicular; X, xenomorphic }\end{array}$ \\
\hline
\end{tabular}


Table 2. Definition and characterization of data fields included in appendix 2 (petrographic data).-Continued

\begin{tabular}{|c|c|}
\hline FIELD_NAME & FIELD_DESCRIPTION \\
\hline AccessMnrls & $\begin{array}{l}\text { Accessory minerals identified by microscopic observation; listed in order of decreasing abundance — abbreviations: Aln, } \\
\text { allanite; Ap, apatite; Ttn, titanite; Zrn, zircon }\end{array}$ \\
\hline XlAlkFld & $\begin{array}{l}\text { Microscope-based estimate of crystallinity of alkali feldspar phenocrysts - abbreviations: A, anhedral; S, subhedral; E, } \\
\text { euhedral. If more than one crystallinity type is present, the dominant form is listed first. }\end{array}$ \\
\hline $\mathrm{XlHbl}$ & $\begin{array}{l}\text { Microscope-based estimate of crystallinity of hornblende phenocrysts - abbreviations: A, anhedral; S, subhedral; E, } \\
\text { euhedral. If more than one crystallinity type is present, the dominant form is listed first. }\end{array}$ \\
\hline $\mathrm{XlBt}$ & $\begin{array}{l}\text { Microscope-based estimate of crystallinity of biotite phenocrysts - abbreviations: A, anhedral; S, subhedral; E, euhedral. If } \\
\text { more than one crystallinity type is present, the dominant form is listed first. }\end{array}$ \\
\hline $\mathrm{XlOpq}$ & $\begin{array}{l}\text { Microscope-based estimate of crystallinity of opaque iron-titanium oxide phenocrysts - abbreviations: A, anhedral; S, } \\
\text { subhedral; E, euhedral. If more than one crystallinity type is present, the dominant form is listed first. }\end{array}$ \\
\hline Petrog_Com & $\begin{array}{l}\text { Groundmass (gndms) characteristics and any otherwise noteworthy features; the degree to which hornblende (Hbl) and } \\
\text { biotite }(\mathrm{Bi}) \text { are oxidized is also noted }\end{array}$ \\
\hline $\mathrm{HblClr}$ & Pleochroic colors of hornblende phenocrysts, if present \\
\hline AltExtnt & $\begin{array}{l}\text { Microscope-based estimate of the extent of alteration where } 1 \text { indicates a completely fresh sample and } 5 \text { indicates a com- } \\
\text { pletely altered sample in which primary textures and minerals are not identifiable; intermediate values of } 2 \text { through } 4 \\
\text { identify progressively more altered samples. }\end{array}$ \\
\hline
\end{tabular}


Table 3. Definition and characterization of data fields included in appendix 3 (geochemical data).

\begin{tabular}{|c|c|}
\hline FIELD_NAME & FIELD_DESCRIPTION \\
\hline Field_ID & $\begin{array}{l}\text { Field-assigned sample identifier; Field_ID entries link data for individual rows to the contents of particular rows in the } \\
\text { other appendices and, for USGS samples, to the National Geochemical Database }\end{array}$ \\
\hline $\mathrm{SiO} 2 \_$pct & Silicon, as silicon dioxide, in weight percent; recalculated to 100 percent on a volatile-free basis \\
\hline $\mathrm{TiO} 2 \_$pet & Titanium, as titanium dioxide, in weight percent; recalculated to 100 percent on a volatile-free basis \\
\hline MnO_pct & Manganese, as manganese oxide, in weight percent; recalculated to 100 percent on a volatile-free basis \\
\hline $\mathrm{MgO} \_$pct & Magnesium, as magnesium oxide, in weight percent; recalculated to 100 percent on a volatile-free basis \\
\hline $\mathrm{CaO} \_$pct & Calcium, as calcium oxide, in weight percent; recalculated to 100 percent on a volatile-free basis \\
\hline $\mathrm{Na} 2 \mathrm{O} \_$pct & Sodium, as sodium oxide, in weight percent; recalculated to 100 percent on a volatile-free basis \\
\hline $\mathrm{H} 2 \mathrm{Ob} \_$pct & Structurally bound or essential water, in weight percent \\
\hline H2Om_pct & Nonessential moisture, in weight percent \\
\hline $\mathrm{CO} 2 \_$pct & Carbon dioxide, in weight percent \\
\hline F_pct & Fluoride, in weight percent \\
\hline Total_I_pct & Initial, pre-recalculation sum of oxide abundances, in weight percent \\
\hline Volatile_pct & $\begin{array}{l}\text { Total volatile content, in weight percent; calculated as the sum of moisture, bound water and carbon dioxide, or as the } \\
\text { content lost on ignition }\end{array}$ \\
\hline Ba_ppm & Barium, in parts per million \\
\hline Be_ppm & Beryllium, in parts per million \\
\hline Th_ppm & Thorium, in parts per million \\
\hline U_ppm & Uranium, in parts per million \\
\hline Ga_ppm & Gallium, in parts per million \\
\hline La_ppm & Lanthanum, in parts per million \\
\hline Ce_ppm & Cerium, in parts per million \\
\hline Pr_ppm & Praeseodymium, in parts per million \\
\hline Nd_ppm & Neodymium, in parts per million \\
\hline Sm_ppm & Samarium, in parts per million \\
\hline Eu_ppm & Europium, in parts per million \\
\hline Gd_ppm & Gadolinium, in parts per million \\
\hline Tb_ppm & Terbium, in parts per million \\
\hline Dy_ppm & Dysprosium, in parts per million \\
\hline Ho_ppm & Holmium, in parts per million \\
\hline Er_ppm & Erbium, in parts per million \\
\hline Tm_ppm & Thulium, in parts per million \\
\hline Yb_ppm & Ytterbium, in parts per million \\
\hline
\end{tabular}


Table 3. Definition and characterization of data fields included in appendix 3 (geochemical data).-Continued

\begin{tabular}{|c|c|}
\hline FIELD_NAME & FIELD_DESCRIPTION \\
\hline Lu_ppm & Lutetium, in parts per million \\
\hline Ag_ppm & Silver, in parts per million \\
\hline Co_ppm & Cobalt, in parts per million \\
\hline Cr_ppm & Chromium, in parts per million \\
\hline Sc_ppm & Scandium, in parts per million \\
\hline V_ppm & Vanadium, in parts per million \\
\hline $\mathrm{Cu} \_$ppm & Copper, in parts per million \\
\hline Mo_ppm & Molybdenum, in parts per million \\
\hline $\mathrm{Pb} \_p p m$ & Lead, in parts per million \\
\hline Ta_ppm & Tantalum, in parts per million \\
\hline As_ppm & Arsenic, in parts per million \\
\hline $\mathrm{Sb} \_p p m$ & Antimony, in parts per million \\
\hline B_ppm & Boron, in parts per million \\
\hline Delta_180 & $\begin{array}{l}1,000 \text { times the stable isotope ratio of }{ }^{18} \mathrm{O} \text { to }{ }^{16} \mathrm{O} \text { relative to the same ratio in a standard (usually SMOW, standard mean } \\
\text { ocean water) minus } 1 \text {, in parts per thousand (per mil) }\end{array}$ \\
\hline 87Sr_86Sr_I & $\begin{array}{l}\text { Initial isotope ratio of }{ }^{87} \mathrm{Sr} \text { (generated by radioactive decay of }{ }^{87} \mathrm{Rb} \text { ) to }{ }^{86} \mathrm{Sr} \text {; except data from Ormerod (1988) (Age } \\
\mathrm{Src}=7 \text { ), which are measured }{ }^{87} \mathrm{Sr} /{ }^{86} \mathrm{Sr} \text { ratios; initial ratios are calculated from measured }{ }^{87} \mathrm{Sr} /{ }^{86} \mathrm{Sr} \text { ratios and assigned } \\
\text { sample ages based on radiometric dating of units }\end{array}$ \\
\hline
\end{tabular}




\section{Acknowledgments}

Geologic mapping and sample collection for this study were conducted as part of the Mineral Systems of the Ancestral and Modern Cenozoic Cascades Arcs Project funded by the U.S. Geological Survey Mineral Resources Program. Constructive reviews by Matthew Granitto and S.M. Smith are much appreciated and helped clarify data presentation.

\section{References Cited}

Al-Rawi, Y.T., 1969, Cenozoic history of the northern part of Mono Basin (Mono County), California and Nevada: Berkeley, Calif., University of California, Ph. D. dissertation, $163 \mathrm{p}$.

Chesterman, C.W., Chapman, R.H., and Gray, C.H., Jr., 1986, Geology and ore deposits of the Bodie mining district, Mono County, California: California Division of Mines and Geology Bulletin 206, 35 p.

Fleck, R.J., du Bray, E.A., John, D.A., Vikre, P.G., Cosca, M.A., Snee, L.W., and Box, S.E., 2015, Geochronology of Cenozoic rocks in the Bodie Hills, California and Nevada: U.S. Geological Survey Data Series 916, 26 p., http:// dx.doi.org/10.3133/ds916.

Gilbert, C.M., Christiansen, M.N., Al-Rawi, Yehya, and Lajoie, K.R., 1968, Structural and volcanic history of Mono Basin, California-Nevada, in Coats, R.R., Hay, R.L., and Anderson, C.A., eds., Studies in volcanology: Geological Society of America Memoir 116, p. 275-329.

Gill, J., 1981, Orogenic andesites and plate tectonics: New York, Springer-Verlag, $390 \mathrm{p}$.

Guilbert, J.M., and Park, C.F., Jr., 1986, The geology of ore deposits: New York, Freeman, 985 p.

John, D.A., du Bray, E.A., Fleck, R.J., Vikre, P.G., Box, S.E., and Moring, B.C., 2012, Miocene magmatism in the Bodie Hills volcanic field, California and Nevada: A long-lived eruptive center in the southern segment of the ancestral Cascades arc: Geosphere, v. 8, p. 44-97.

Kingdon, S.A., 2016, Pliocene to late Pleistocene magmatism in the Aurora Volcanic Field Nevada and California, USAA petrographic, geochemical, and isotopic study: Ottawa, Canada, Carlton University, Masters thesis, 229 p.

Lange, R.A., and Carmichael, I.S.E., 1996, The Aurora volcanic field, California-Nevada: Oxygen fugacity constraints on the development of andesitic magma: Contributions to Mineralogy and Petrology, v. 125, p. 167-185.
Lange, R.A., Carmichael, I.S.E., and Renne, Paul, 1993, Potassic volcanism near Mono Basin, California: Evidence for high water and oxygen fugacities inherited from subduction: Geology, v. 21, p. 949-952.

Laniz, R.V., Stevens, R.E., and Norman, M.B., 1964, Staining of plagioclase feldspar and other minerals with F.D. and C. red no. 2: U. S. Geological Survey Professional Paper 501-B, p. B152-B153.

Le Bas, M.J., Le Maitre, R.W., Streckeisen, Albert, and Zanettin, Bruno, 1986, A chemical classification of volcanic rocks using the total alkali-silica diagram: Journal of Petrology, v. 27, p. $745-750$.

O’Neil, J.R., Silberman, M.L., Fabbi, B.P., and Chesterman, C.W., 1973, Stable isotope and chemical relations during mineralization in the Bodie mining district, Mono County, California: Economic Geology, v. 68, p. 765-784.

Ormerod, D.S., 1988, Late- to post-subduction magmatic transitions in the western Great Basin, U.S.A: Milton Keynes, United Kingdom, Open University, Ph. D. dissertation, 331 p.

Osborne, M.A., 1985, Alteration and mineralization of the northern half of the Aurora mining district, Mineral County, Nevada: Reno, Nevada, University of Nevada, M.S. thesis, $93 \mathrm{p}$.

Silberman, M.L., and Chesterman, C.W., 1972, K-Ar age of volcanism and mineralization, Bodie mining district and Bodie Hills volcanic field, Mono County, California: Isochron/West, no. 3, p. 13-22.

Silberman, M.L., and Chesterman, C.W., 1995, A description of the Bodie Hills and Bodie mining district, Mono County, California, in Jones, Elizabeth, ed., Geology and ore deposits of Bodie Hills, northern Mono Basin region; Bodie Hills, Aurora district: Geological Society of Nevada Special Publication, v. 22, p. 2-8.

Silberman, M.L., and McKee, E.H., 1972, A summary of radiometric age determinations on Tertiary volcanic rocks from Nevada and eastern California - part II, western Nevada: Isochron/West, no. 4, p. 7-28.

Streckeisen, Albert, 1976, To each plutonic rock its proper name: Earth-Science Reviews, v. 12, p. 1-33.

Taggart, J.E., Jr., 2002, Analytical methods for chemical analysis of geologic and other materials: U.S. Geological Survey Open-File Report 02-0223, available at http://pubs. usgs.gov/of/2002/ofr-02-0223/OFR-02-0223.pdf.

U.S. Geological Survey, 2008, National geochemical database: Reston, Va., U.S. Geological Survey, available at http:// mrdata.usgs.gov/ngdb/. 


\title{
Appendix 1. Status and Treatment of Samples
}

\section{Appendix 2. Petrographic Data for Rock Samples}

\author{
Appendix 3. Geochemical Data for Rock Samples
}


Publishing support provided by:

Denver Publishing Service Center

For more information concerning this publication, contact:

Center Director, USGS Central Mineral and Environmental Resources Science Center

Box 25046, Mail Stop 973

Denver, CO 80225

(303) 236-1562

Or visit the Central Mineral and Environmental Resources Science Center Web site at:

http://minerals.cr.usgs.gov/ 
